\title{
The Role of Tourism in Urban Conservation: The Case of Manila, The Philippines
}

\section{Şehirsel Korumada Turizmin Rolü: Manila Örneği, Filipinler}

\author{
Adem YULU ${ }^{1}$ (D), Kaan $\mathrm{KAPAN}^{2}$ (]) \\ ${ }^{1}$ Igdir University, Faculty of Sciences and Letters, Department of Geography, Igdir, Turkey \\ ${ }^{2}$ Istanbul University, Faculty of Letters, Department of Geography, Istanbul, Turkey
}

ORCID: A.Y. 0000-0001-8037-259X; K.K. 0000-0003-2979-5057

\begin{abstract}
Different types of physical assets of historical origin such as structures, monuments, and squares are conserved by improving them through various restoration techniques, enabling them to have a touristic function. We witness an increasing number of district-scale or structure-scale restorations and conservations where structures throughout the world, particularly in the inner-city areas of the old city, eventually gain economic value in terms of recreational and touristic activities. The concept of "conservation" has started to play a vital role in most of the colonial capital cities in Southeast Asia, especially those connected to the coast. The role of conservation action in revitalizing the old cities in the Philippines, a former Spanish colony in Southeast Asia, earns them touristic-recreational functions. Most of the historical coastal cities, even in the pre-colonial period, such as Manila, which is a focal centre of the country in terms of cultural, political and economic activities, form the basis of the cultural heritage tourism of the country. The objective of this study concerns the restoration of the structures located in the historical inner-city area of Manila to take them under conservation and use them for touristic purposes.
\end{abstract}

Keywords: Urban conservation, tourism, Philippines, Manila

Submitted/Başvuru: 26.02.2020 • Revision Requested/Revizyon Talebi: 18.04.2020 • Last Revision Received Son Revizyon: 01.05 .2020 • Accepted/Kabul: 31.05.2020 • Published Online/Online Yayın: 07.08.2020

Corresponding author/Sorumlu yazar: Adem YULU / adem.yulu@igdir.edu.tr Citation/Atıf: Yulu, A. \& Kapan, K. (2020). The role of tourism in urban conservation: The case of manila, The Philippines. Cografya Dergisi, 41, $13-27$. https://doi.org/10.26650/JGEOG2020-0011 


\section{INTRODUCTION}

Built-up space, considered as a living being, transforms by renovating itself in natural and organic ways over time (Treister, 1987). Mostly, the effect of touristic and recreational activities on the realization of this transformation, which most often occurs as a natural process, are emphasized (Hall and Page, 2006).

Historical streets, districts and cities considered as historical and cultural heritage are now seen as assets required to be conserved ${ }^{1}$ and such conservation is mostly supported by various funds (Ahunbay, 2017, p. 8). In the conservation of historical environments or of those environments which are important for human beings, "economic stimuli", rather than "conservation of historical and cultural heritage", take precedence (Özgüç, 1988-1992). Thanks to tourism, urban infrastructure and superstructure are improved, making the cities attractive liveable places. As a matter of fact, this development and emergence of mass tourism in the nineteenthcentury Europe and vacation opportunities, all lead quickly to the construction of cities and holiday resorts for daily excursions and cause the capital to shape the nature (Mullins, 1994).

Efforts to protect signs of the past increasingly receive more support and the number of cities with historical and cultural characteristics taken under conservation is increasing gradually. The city of Vigan, established by the Spanish to the north of the Philippines for reinforcement of the commercial network across the colonial regions in the $16^{\text {th }}$ century has, for example, become a regional tourism destination after the city was declared by UNESCO as a "heritage site" (Cruz, 2017). According to UNESCO data, while the number of tourists visiting Vigan was 76,000 in 2009, the number exceeded 1.4 million in 2017.

In the coastal cities' historical inner-city areas in the Philippines, particularly Manila, a colonial capital city (along with Davao, Cebu, İloilo, Zamboanga, etc.), renovation and restoration have been neglected because of either their high cost or of the fact that social awareness about historical assets has not developed in a real sense. Especially in the historical coastal cities, renovation and restoration operations were neglected, except for monumental buildings and squares from the colonial period. For this reason, in Manila, actual examples of historical conservation have remained limited up to recent years with respect to urban renovation.
Although some researchers consider Manila "as a city worth visiting, but not so appropriate for living", it is emphasized that Manila (Öncü and Weyland, 2007), particularly its historical inner-city area, started to take its place in the restoration movement for old historical buildings, touristic hotels, boutiques and cafes in recent years, especially through the efforts of foreign entrepreneurs (and due to the significant effect of the fact that the Philippines has increasingly emerged as a new tourist attraction).

\section{MATERIALS AND METHODS}

As stated by Tümertekin (1997), being places where the effects of human intervention reach high levels, cities undergo changes constantly. Consequently, such changes require continuous observation of the cities by the geographers. This study primarily deals with the conceptual relationship of urban conservation and tourism and it is supported by observation and research on-site by visiting Cambodia, Thailand, Singapore, and the Philippines at different times in order to discuss this matter on an areal/spatial basis. My position as a visiting scholar at the University of the Philippines during the period of February-June 2019 has made a significant contribution to this study and to the detailed examination of historical and cultural traces in the region and Manila (Intramuros, Binondo, Quiapo) as well as to their transformation into geographical observations. Additionally, the relationship between urban conservation and tourism has been studied in Southeastern Asia as a region, the Philippines as a country and Manila as a city, and observation has been made in the historical coastal cities with historical heritage dating back to the Spanish colonial times in the islands of Luzon, Visayas and Mindanao in the Philippines.

\section{THE ROLE OF TOURISM IN URBAN CONSERVATION}

In the $21^{\text {st }}$ century, as a result of rapidly changing technology, lifestyle and consumption habits, human perception about space with respect to architectural structures and geographical factors reflecting the identity of a city changes as well. It is not hard to understand that even an architectural structure built in the last 200 years, may draw the attention of tourists in search of authenticity (e.g. Rome in Italy, Budapest in Hungary, Beyoğlu in Istanbul), and that they are currently under conservation by the city authorities.

1 As a result of increased interest in the conservation of the built-up environment, the first scientific meeting with a large attendance on urban renovation worldwide was held in Holland, 1958 (Broudehoux, 1994, p. 10). Serious damage to historical and cultural assets which were subject to air raids during the World War II, played a particularly significant role in this regard. 
Conservation efforts, mostly found in the central inner-city area, are now an integral part of urban planning policies. For example, gentrification emerged in the early 1980s at the city scale and has now become the strategy of becoming a global city. However, those witnessing this process are not only the prominent cities around the world such as London, Sydney, New York or Amsterdam (Smith, 2017, p. 280), but also the metropolises such as Beirut, Manila, and Istanbul, which experience all the contradictions and pains of globalization in different ways and intensities (Öncü and Weyland, 2016). Efforts are made to make the central inner-city areas of the cities attractive in terms of tourism by means of urban conservation and applications and different ways of getting high gains from touristic activities in these places are explored (Smith, 1988). When doing this, the cities aim to create an environment to provide a high quality of life to their dwellers and promote such an environment to the outside world by using strategic marketing methods. And when they succeed, it (city tourism) is expected to contribute to the development of their regions/countries (Emekli, 2011). Moreover, destination image is an important phenomenon for touristic mobility and the specification of touristic attractions (Rewtrakunphaiboon, 2009, 2; Güngör, Ş. and Uysal, A. 2019).

The importance of the conservation of structures with historical heritage in improving people's quality of life has increasingly been better understood (Tekeli, 2014, p. 274). We see many examples of it, particularly in developed countries such as the United Kingdom, which are very rich in terms of historical and cultural assets (Williams, 1998). Furthermore, it is also very important to design, manage, protect, and make the cities sustainable in terms of the concept of "the right to the city," a term which was used by David Harvey, meaning to design them in accordance with the desires of the residents and visitors. The question of what kind of a city we desire cannot be thought separately from what kind of individuals and social relations we pursue and the relations we build with nature and the importance we attach to the aesthetic values and the lifestyle and interests we adopt (Park, 1967; Harvey, 2012).
The effect of tourism, its so-called "reproductive effect", based on the assumption that tourism expenditures would also vitalize other sectors of the economy and increase employment has also been accepted as a kind of focal point in various studies. Although it is difficult to measure the exact reproductive effect of tourism (Özgüç, 2017, p. 163), it is, especially in the historical inner-city areas, mostly felt soon through urban renovation practices $^{2}$.

Conservation of the rehabilitated historical assets by using them for tourism and recreational purpose is mostly considered among the best methods for conservation of historical structures (Smith,1988, s. 246). As it is, allocation of certain budgets for conservation planning with respect to avenues, and even cities, which have high touristic potential and are intensively visited by local and foreign tourists, is a frequently encountered phenomenon (Shaukland, 1996, p. 24). Areas in the cities which are rehabilitated by way of conservation and which have gained a recreational function become favourite locations over time (Castells et al., 1990). Conservation efforts worldwide reflect this fact clearly. For example, in Singapore, locations with rich historical assets pertaining to Chinese, Indian and Arabian cultures (buildings with old architecture) were rehabilitated and conserved by means of district-scale projects (Photo 1).

In Singapore, the conservation policy which affects urban view has been successful and efforts to this effect have been made by rehabilitation and conservation of the historical buildings by means of restoration in different parts of the country (Photo 2).

While revitalization of the historical inner-city areas is mostly by way of improvement of infrastructure, cleaning and conservation of worn-out buildings by means of various renovation practices increase the real property value of the land and buildings. They also make these locations favourite areas, especially for tourism and recreation. We see an increasing number of similar examples worldwide like Singapore. In many cities of Europe where we frequently witness the phenomenon "conservation of a historical city as a whole", old street patterns

2 In this century where new urban development is increasingly standardised, leading to loss of identity (Shaukland, 1996), while Singapore is reconstructed as a whole, it poses a threat to developing tourism, resulting in a decrease in the number of tourists visiting the country (Smith,1988, p. 250). The reason was that when Singapore was the Manhattan of Asia in early 1980, it started to resemble other cities of the world. While Singapore has lost its Asian quality, it has started to be deprived of its interesting nature in a cultural sense (Chua,1997). For example, as the cultural and physical factors created by the Chinese, English and Arabian people altogether in this country where they settled for economic reasons (Chinatown, Little India, Colonial Inner-City and Sultan Mosque's Arabian Quarter, Kampong Glam and similar quarters) have been neglected, the city had become less attractive to tourists (Özgüç, 1988-1992, p. 115-116). So the Singapore Tourism Encouragement Department and planning institutes launched a joint initiative to "protect historical districts in the central areas of the city". Singapore conserved "traditional" locations where Chinese, MalayArabians and Indians dwell. Instead of restoration, the building weres reconstructed according to their original designs and painted colourfully. Also, the inner spaces of the buildings were changed and offices, stylish restaurants and bars were opened (Chua,1997). 


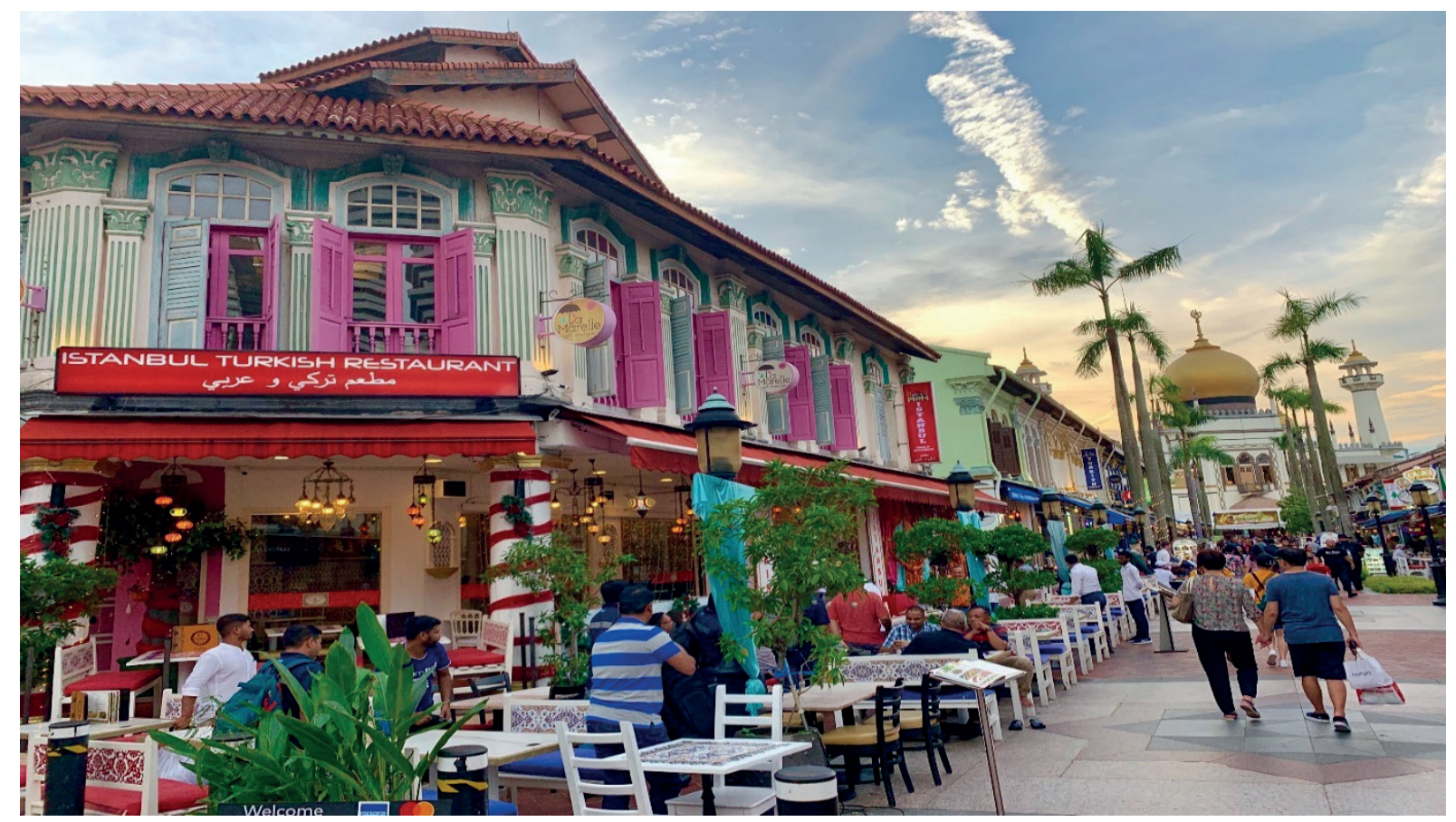

Photo 1: Rehabilitated buildings through conservation in Singapore (Malay-Muslim Quarter).

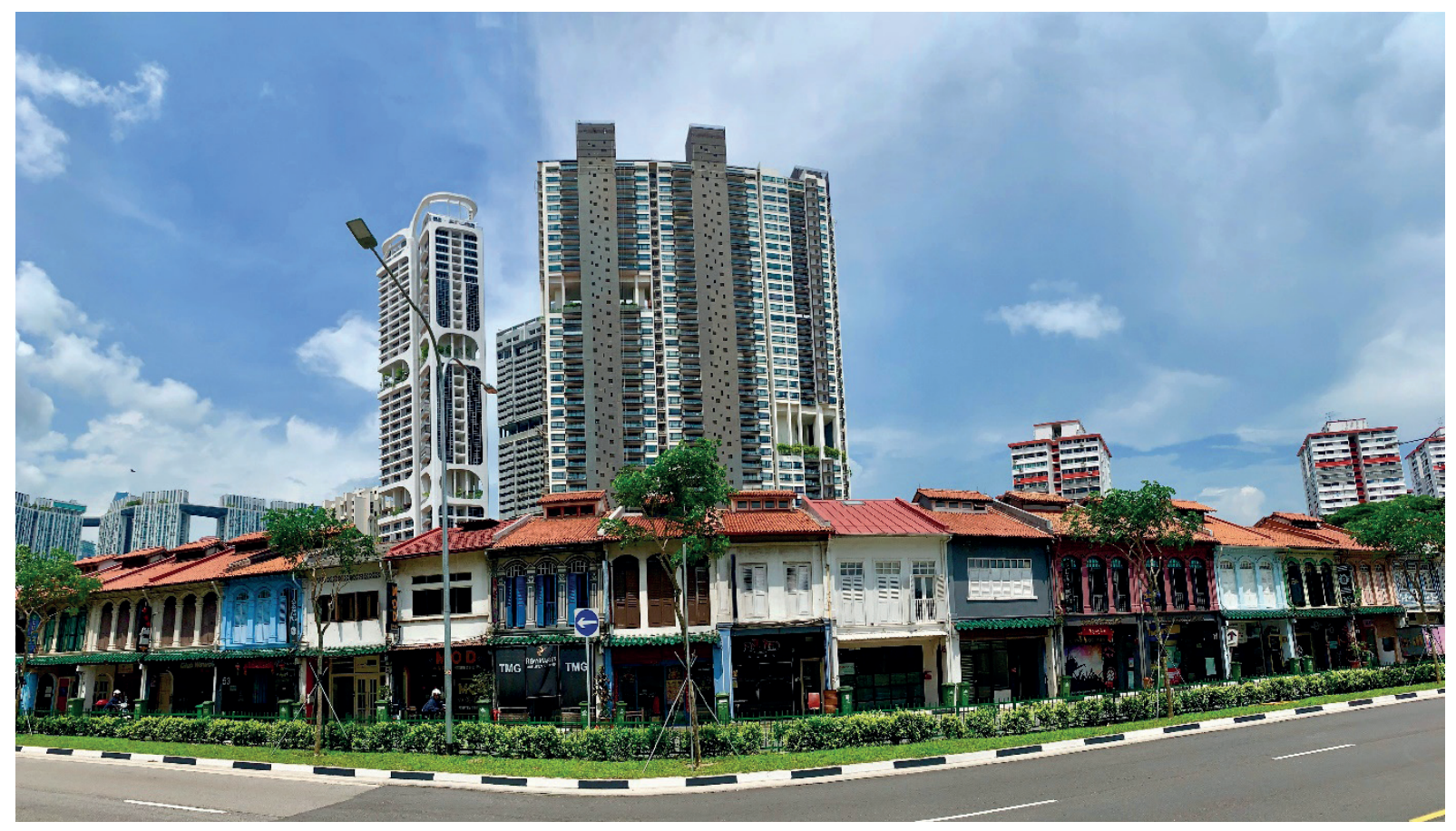

Photo 2: Buildings rehabilitated by conservation along Joo Chiat Avenue (Singapore).

succeeded in protecting their attractiveness by adapting themselves to new economic conditions in relation to tourism, such as recreational activities. Considerable gains have been obtained from tourism and recreational activities as a result of increased value in small and carefully confined locations mostly in the inner-city areas such as Bath, Chester and Norwich in the
United Kingdom; Bruges in Belgium; Frankfurt in Germany and Venice in Italy (Tümertekin, 1988, p. 9).

Recognizing the potential of the revitalization of the cities of historical significance in Asia to contribute to the economy, the Asian Development Bank developed a number of urban strategies 


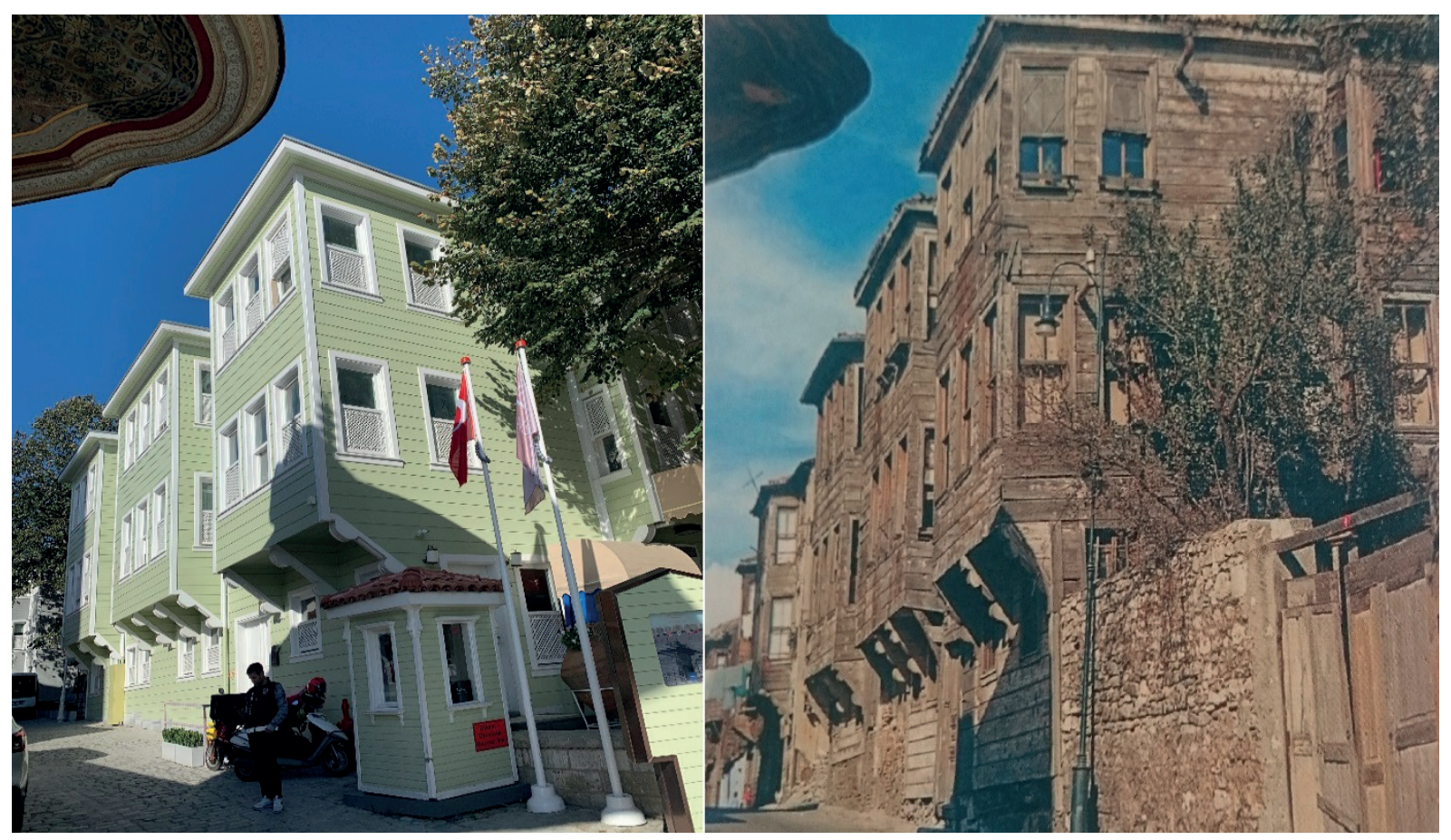

Photo 3: Old and new views of Hagia Sophia Mansions in Soğukçeşme Street, Hagia Sophia.

with a view to the revitalization of these areas. By doing so, the Asian Development Bank provided financial and credit support to public and private organizations for the restoration and conservation of the historical buildings even though these were building-scale efforts (Steinberg, 2008). In accordance with the strategies developed by it especially with respect to central inner-city areas established after the colonial period in the border countries in Asia and Pacific, the Asian Development Bank has, thanks to the support it provided, played an important role in the identification of deformations in the city in many places and the discontinuation of such deformation and valuation of lands and properties there. For example, in post-colonial cities such as Phnom Pen in Cambodia, Hanoi in Vietnam, and Jakarta in Indonesia, the Asian Development Bank has made significant contribution to the historical conservation of the inner-city structure of these cities . In Turkey, Istanbul, where we frequently encounter examples of urban inner-city areas, may be regarded as a good example with a significant number of urban renovation cases. Under "The Project on Conservation and Development of Sultanahmet Square Vicinities and Hagia Sophia Soğukçeşme Street" launched for Sultanahmet and immediate vicinity where traces of historical development of Istanbul are present, the old houses with historical value were rehabilitated and put into service for touristic purposes (Eldem, et al., 1979, p. 19). The Hagia Sophia Mansions reflecting late Ottoman architecture were restored by the Turkish Touring and Automotive Club as a contribution to cultural life and tourism (Photo 3).

While "economic stimuli" are effective in restoring historical buildings in the inner-city areas and mostly in imparting them a recreational function and thus making these districts favourite spaces, the intention to "give the space new attractions" and "spread the historical awareness to new generations of the society" plays a significant role.

Today, while districts mostly used for recreational purposes have become prominent attraction centers, many countries get significant gains from such touristic activities. Revitalization of the historical inner-city areas mostly by way of improving the infrastructure, cleaning, and conservation of worn-out buildings by means of various renovation practices increases real property value of the land and buildings ${ }^{3}$.

Looking at the phenomenon of urban conservation merely from an economic perspective also causes such an impression that this event is not understood properly. This concept and its phenomena, particularly in the case of developed countries, are also evaluated considering the following factors: $3^{\text {rd }}$ Generation Right, environmental right, self-determination right of the communities, right of collective use of the existing assets, and

3 It is generally observed in "other cities in our country like Antalya which are prominent with their touristic function" (Kapan, 2018). 


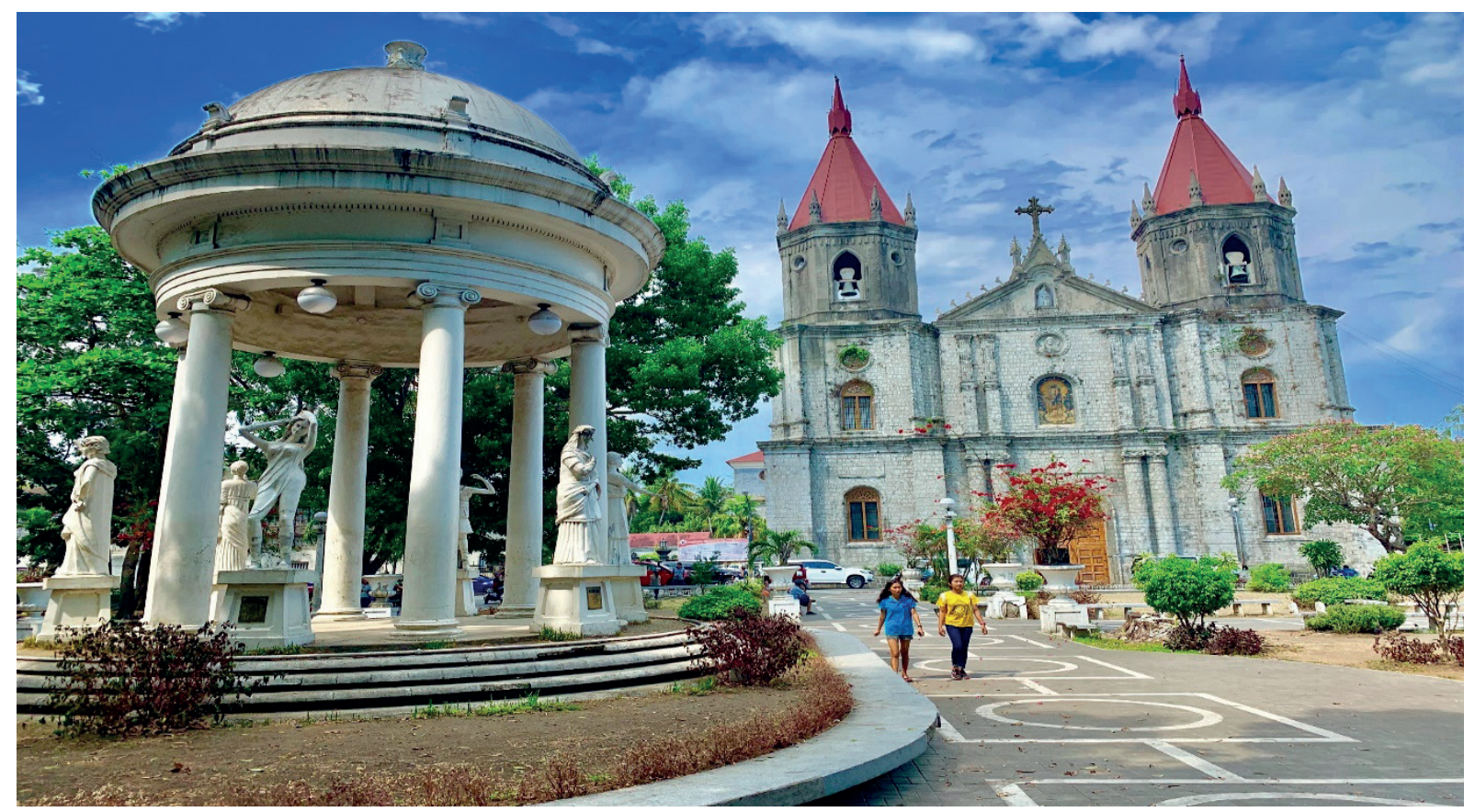

Photo 4: St Anne's Molo Church build with gothic architecture in 1831, Iloilo.

solidarity right (Dadak, 2015). It should be noted that the councils formed long years ago (International Monuments and Sites Council, International Museums Council) and conventions made (Venetian Convention, Convention Concerning Conservation of World Natural and Cultural Heritage) are implemented in line with the economic development of the countries.

While the development of tourism, especially in the relatively smaller countries with low income level, symbolizes the basic source of economic improvement and social development (Shaukland, 1996: 24), conservation of the historical buildings of different characteristics located in the inner-city areas by improving and imparting recreational function to them increasingly gains importance in those countries such as the Philippines which cannot afford the cost of such conservation practices.

\subsection{Urban Renovation in the Philippines}

Most of the big Asian cities connected to the seaside have served as international trade centers for a long time under colonial administrations. And, naturally, inner-city areas of these cities succeeded in surviving up to now with their historical texture, strong buildings, and rich cultural heritage. However, most of these museum-like cities have encountered the risk of being dead cities since the early $20^{\text {th }}$ century substantially because they were neglected and worn out. And Manila, reflecting different characteristics of the colonial period, has been among such locations that encountered urban problems due to a variety of reasons.

Manila is the leader among the places with the presence of a large number of historical and cultural assets in terms of the spatial development of the Philippines. The first important example of urban renovation and rehabilitation operations in Manila (arrangement of city parks, improvement of the transportation system, development of summer-resort areas) was in the American colonial period (the early 1900s) (Munárriz et.al., 2015, p. 80). However, a large-scale movement of urban renovation in the Philippines started with the financial support given by the World Bank in 1972 with projects for identification and improvement of the slummed area "with priority for arrangement," starting from the slums running along Tondo, the coastline of Manila (Davis, 2006, p. 73). Moreover, upon the failure of this project, the World Bank focused on the slum areas located in other cities outside Manila such as Cebu, Davao and Cagayan de Oro in 1979 (Beltran, 1982, p. 18). But urban renewal projects in the country were halted or put on hold when the country underwent a financial debt crisis in the 1980s (Berner, 1988). Financial resources that could have been used to renew and revitalize urban areas were instead used in refinancing the country's debt. It was also because of the economic crisis that people from rural areas moved to urban areas seeking jobs 

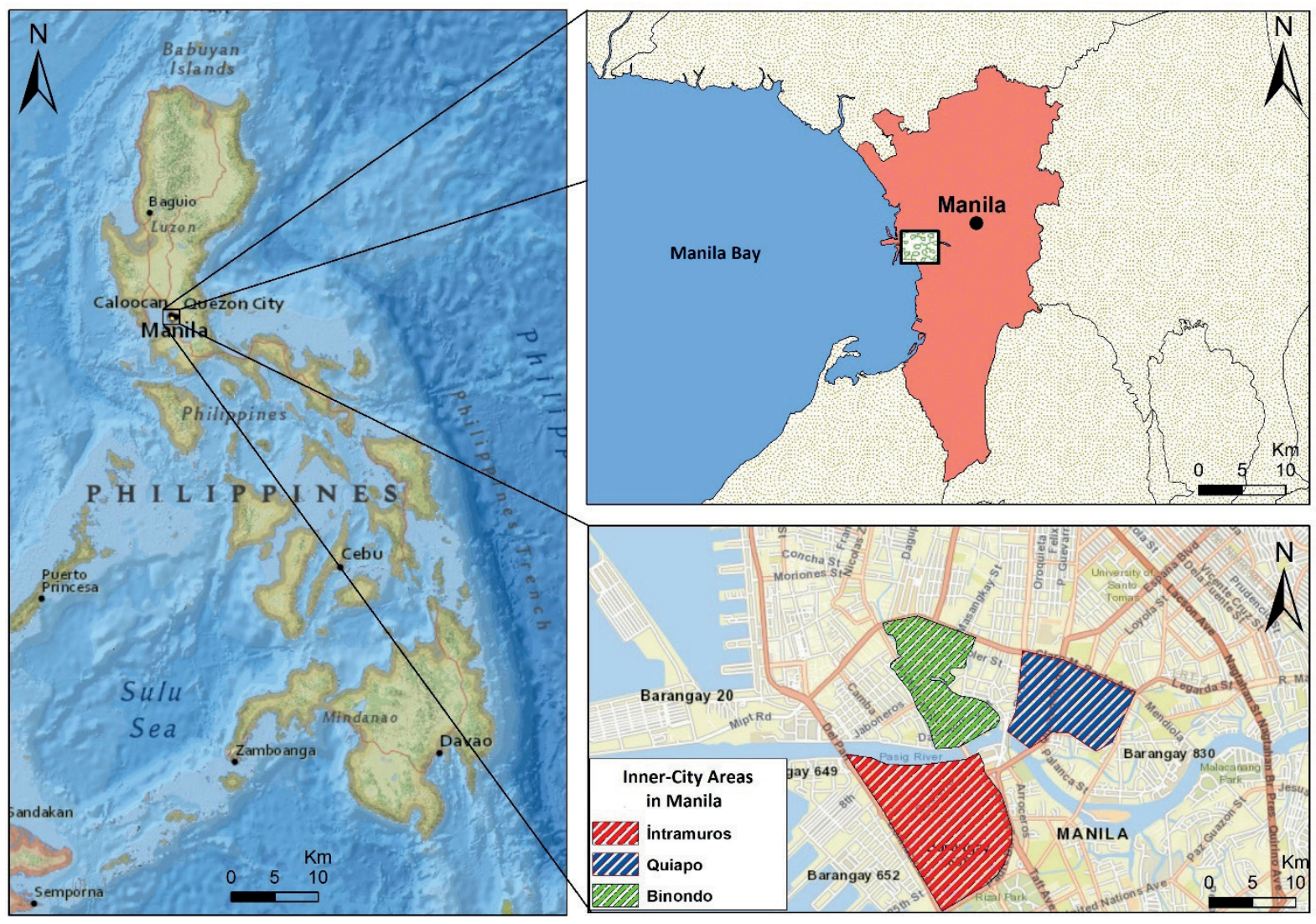

Figure 1: Districts with concentrated historical conservation in Manila.

(Flieger, 1977). This migration contributed to the growth in urban slum areas and adding further pressure to urban infrastructures. While "urban transformation projects" were mostly in the slum areas outside the inner-city area and built up as a result of immigration, "urban conservation" has gradually gained importance in the historical inner-city areas connected to the coast.

In the Philippines, the conservation phenomenon has continued mostly at the building scale until quite recently. Residences of the Philippine leaders, historical squares and historical buildings take the lead in this respect. Conservation of the historical buildings from the colonial period in those coastconnected cities of the Philippines (e.g. Manila, Vigan, Davao, Iloilo, Cebu, etc.) has individually been quite successful in recent years. For example, the cities of Illoilo ${ }^{4}$ and Vigan are primary locations where Spanish historical and cultural heritage is most conserved in Asia (Photo 4).
Although urban transformation projects at the district scale are frequently encountered outside the inner-city area in the Philippines, we hardly witness renovation and conservation practices at the district scale in the inner-city areas in the country. Rather, we see practices at street and building scales due to economic reasons and lack of demand for district-scale projects among the public and local authorities.

\subsection{Urban Conservation in Manila}

Historical conservation has become a part of urban renovation policies in many districts remaining within the inner-city area of Manila. It affects most of the districts in the inner-city area. Small inner-city areas, known as Intramuros, and Binondo and Quiapo are major ones among those districts where historical and cultural assets of the country are intensive (Figure 1).

In Manila, along with the tours and related developments especially in recent years, there are examples of conservation for

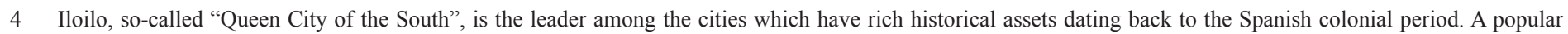

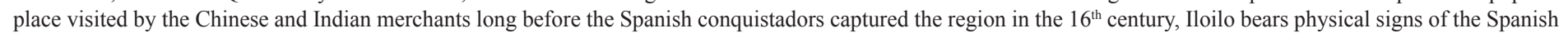
colonial period with its gorgeous churches, spectacular houses and other still remaining historical structures. 
recreational purposes in the inner-city area. Among the districts where these examples are concentrated, Intramuros has a leading status ${ }^{5}$.

\subsubsection{Walled City: Intramuros}

While the Spanish built thick walls around Intramuros, they also constructed the government office at a carefully selected location, followed by San Augustin Church and University of Santo Tomas thereafter (Vaughan, 1956, p. 22-26). The reason for the existence of Intramuros is spatial institutionalization, a focal point of the pre-industrial centralism ${ }^{6}$.

Intramuros or so-called walled city, forming the inner-city area of Manila, was heavily destroyed due to air raids and resulting fires during World War II (De Roos, 1966, p. 311). More than $90 \%$ of the historical buildings as cultural heritage from the Spanish colonial period had been damaged (Turalba, 2008, p. 164).

Ruins from the war were cleared away and efforts were made to reconstruct some of the historical buildings in Intramuros, remaining loyal to their original scale, such as the Manila Cathedral. But reconstruction work was hampered by the need to rebuild public infrastructures such as roads and bridges. There was also a need to restart industrial and commercial activities and this took precedence over reconstructing cultural and historical sites (Figure 2).

Large-scale restoration works in Intramuros are based on the declaration of Intramuros as a national conservation and historical monumental area in 1951. To this end, the "Intramuros Restoration Committee" was set up in 1966. In the beginning, historical walls and buildings in Intramuros were restored through governmental funds and aid with the involvement of the Intramuros Restoration Committee (IRC) and the private sector. However, upon proclamation of Martial Law in 1972, IRC was

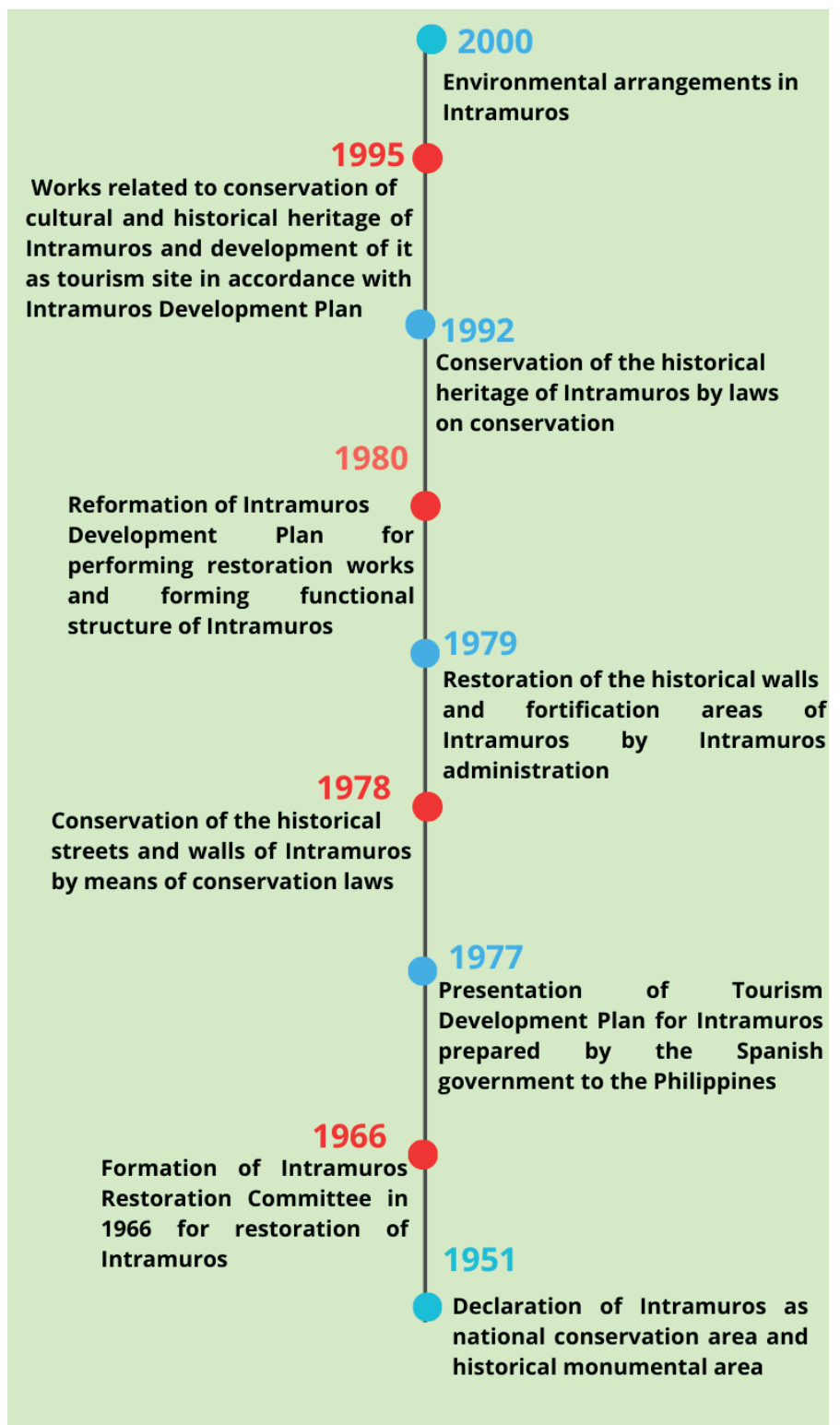

Figure 2: Evolution of urban renovation process in Intramuros. (Steinberg, 2008).

abolished. Then in 1979, the management of Intramuros was handed over to the Intramuros Administration. Among others,

544 years after Magellan was killed in the Mactan War in 1521, The Philippines, the Spanish came to the Philippines in 1565, this time under the leadership of Spanish Don Miguel de Lagaspi and constructed Fort Santiago at the estuary of River Pasig, andthus laid the foundation of Intramuros. Flourishing as the centre of the Spanish colonial administration, Intramuros was surrounded by thick walls (Vaughan, 1956, p. 22-26). While it was a small Pacific coast facing settlement, populated by 2000 natives, in 1571, it gained a multi-ethnicity identity with a population over 40,000 (upon arrival of Spanish conquistadors and Chinese merchants) in 1620 (Bankoff, 2006 : 413). Subsequently, transformed to a coast city thanks to its commercial seaports, it took the name of Manila. Thanks to the trade between Acapulco port in Mexico and Manila conducted by the Spanish during the period 1593-1815, Manila became a primary commercial seaport in the Pacific for east-west trade. Manila was also the focus of the nationalist movement which gradually gathered strength throughout the $19^{\text {th }}$ century. This led to the Philippine Revolution of 1896 . It was during the second phase of the revolution in 1898 that the Americans entered the Philippines. A war then broke out between the Filipinos and Americans which resulted in the Americans taking over the country in 1901. In the same year, the new colonial government passed the City Charter of Manila, which expanded the border of Manila beyond the walled city to include the former suburbs, among them Binondo, Malate, Ermita and Quiapo. It was from this time that Walled City came to be known as Intramuros rather than Manila (Caoili, 1988)

6 In his book Development of Urban Centralism, Jean Gottmann claims that roots of a central place in the pre-industrial world were connected to the functions of the castle (administrative function), the market (trade junction function) and the temple (emergence of any religion in the society in the form of collective rites), he also remarked that the focal point of the urban development and centralization after the Industrial Revolution changed to intensive manufacture (Gottmann, 1976, p.19). 
they have built new tourist attractions inside the Walled City such as the Barangay San Luis (Sometimes referred to as Barrio San Luis) which was a reconstruction of houses from various periods of the Spanish Colonial era (Steinberg, 2008). The complex of Casa Manila, having been restored as a museum, also houses a hotel, restaurant, cafés, gift shops, and a bike rental shop. It also hosts a branch of the Spanish cultural institute, Instituto Cervantes (Photo 5).

Upon presentation of the "Intramuros Tourism Development Plan" (1988) by the Spanish government to the Philippine government for restoration of Intramuros as "a historical district" which remained as a reminiscence of the Spanish culture, a new law was passed for the conservation of streets and historical walls in the district.

As a result of intensive restoration works by administrators of Intramuros in the period between 1979-1986 (archival studies, archaeological excavations, preparation of restoration plans, cleaning and construction of archaeological site), Intramuros has, to a large extent, gained its current historical appearance (Turalba, 2008, p. 165). With a series of new laws passed in recent years, historical heritage in Intramuros was completely taken under conservation (Photo 6).
Intramuros is the leader among the districts where conservation was carried out in the most successful way. Efforts were made to protect the areas located in the small inner-city area called Intramuros. Some of the streets here were rearranged and pedestrianized (Photo 7).

Another policy of the Intramuros Administration was to require developers and business owners in Intramuros to build houses and buildings in the colonial style and to stay within a certain height requirement. This has led to the creation of a distinct historical look within the Walled City which has since attracted a large number of visitors.

However, Intramuros, visited by millions of local and foreign tourists each year, was visited by more than 1 million people in "Holy Week" alone according to data for the year 2018 from the Department of Tourism. Still, Intramuros encounters a number of environmental problems with its avenues and streets devoid of sidewalks and its infrastructure getting more and more worn-out every day.

The conservation of Intramuros in this way from the $1950 \mathrm{~s}$ onwards has been largely based on the stimulus for the conservation of historical and cultural heritage, rather than

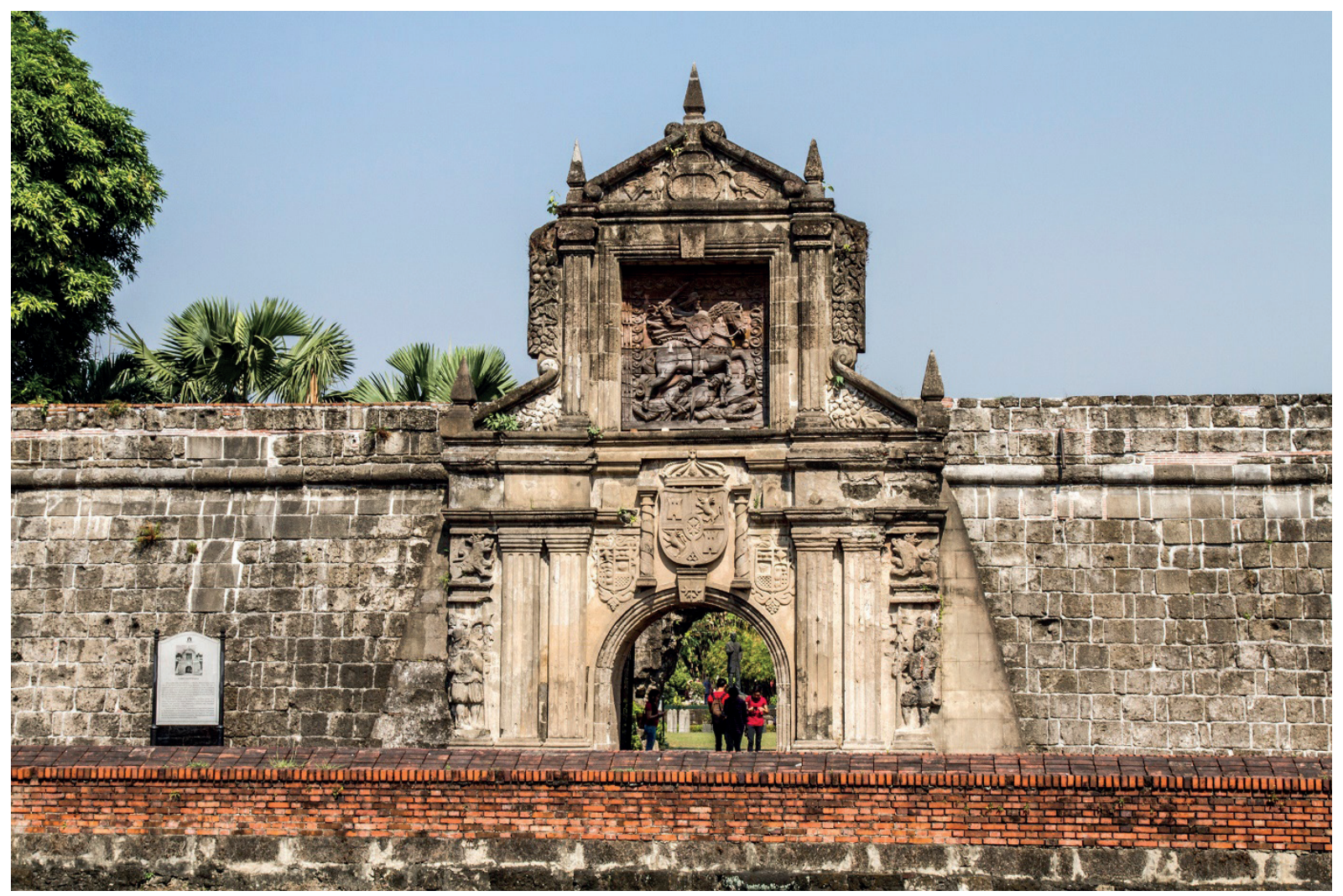

Photo 5: Historical walls of Intramuros. 


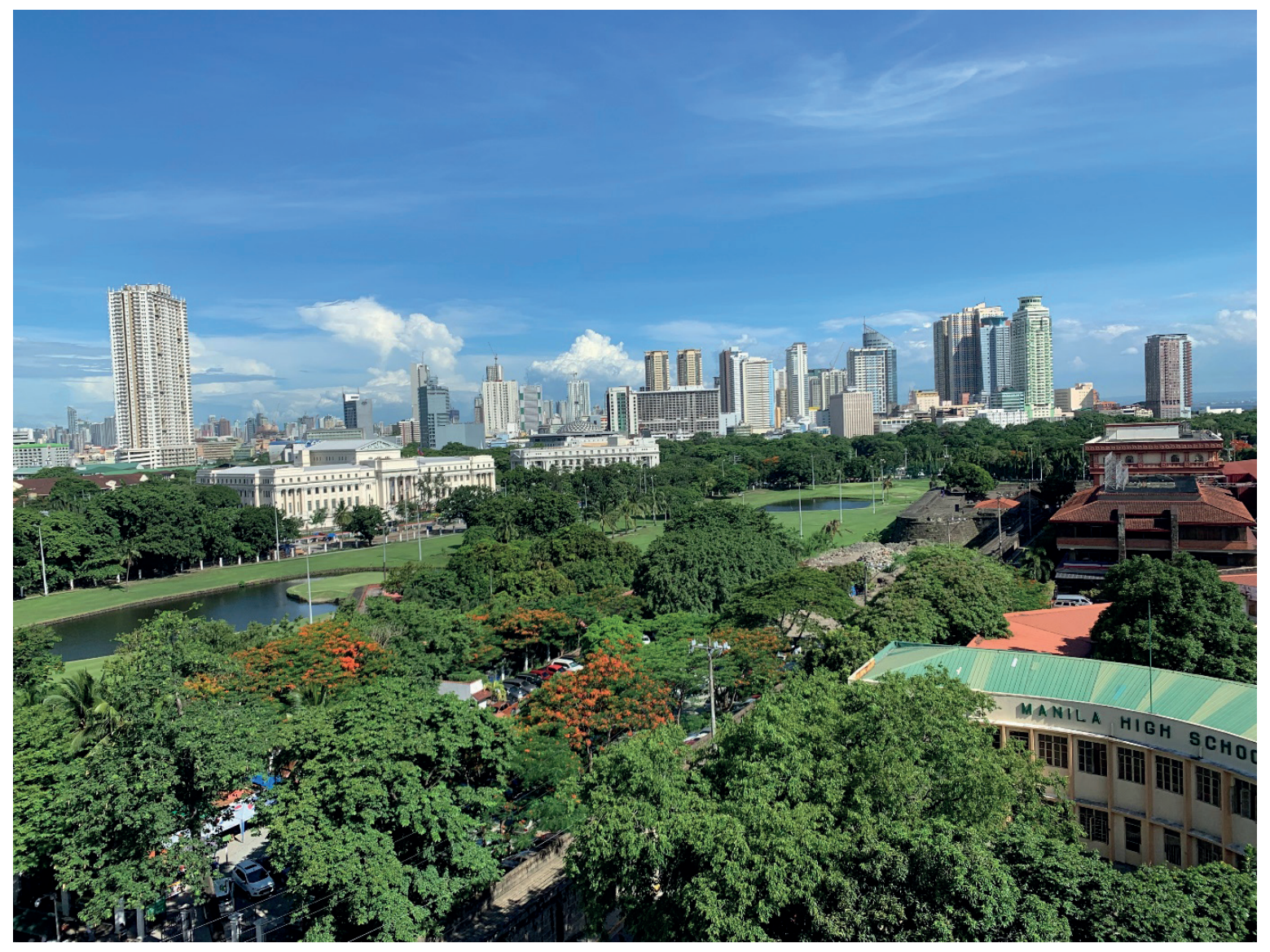

Photo 6: A view of Intramuros.

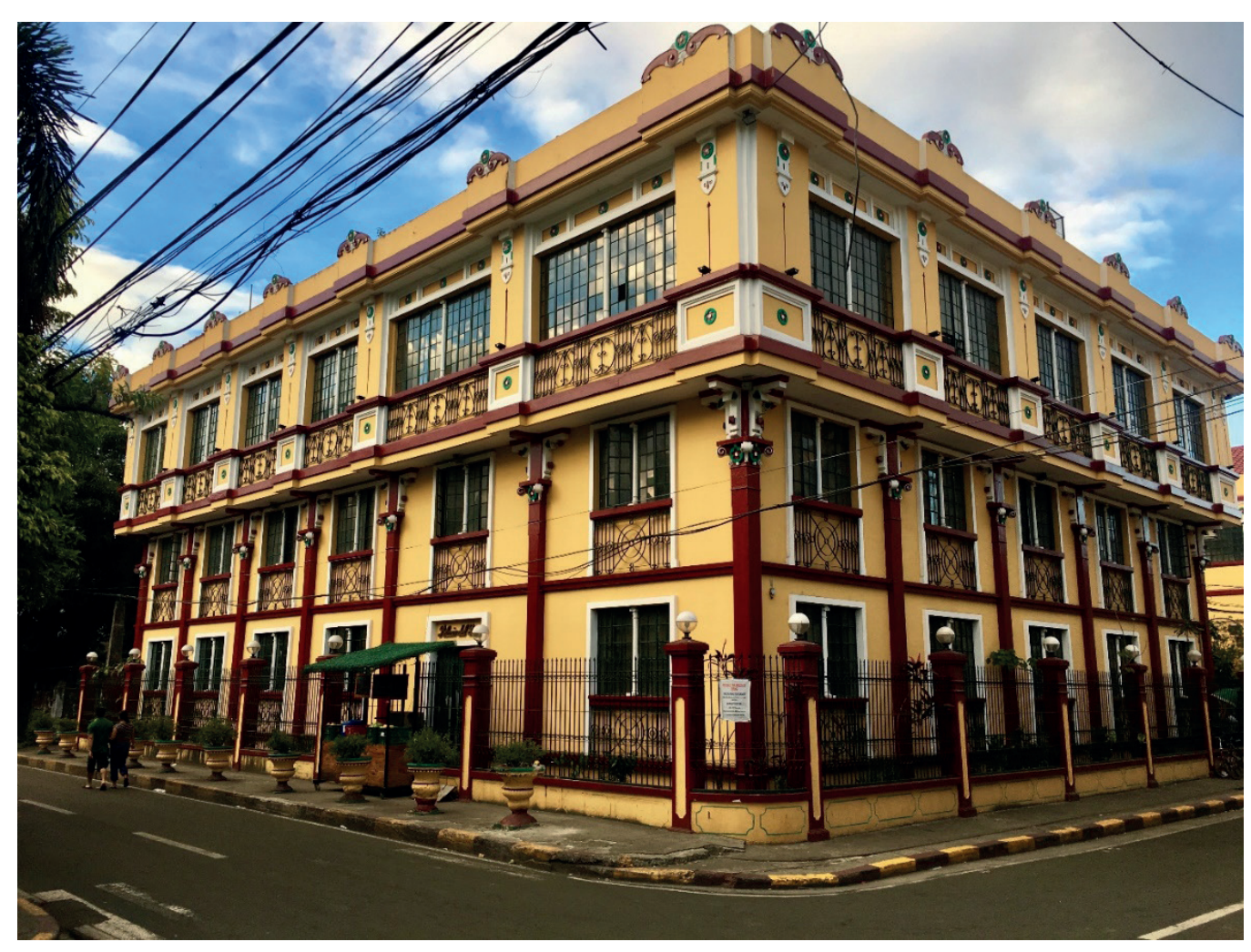

Photo 7: One of the buildings rehabilitated in Intramuros. 
economic motives. However, the number of tourists visiting the Philippines after the 1990s has also made economic motives more visible. The main driving force in this area was tourism and recreational activities.

\subsubsection{Binondo: One of the Oldest Chinatowns in the world}

Along with Intramuros, Binondo, also called Chinatown, constitutes another important part of the inner-city area. Despite the significant impact of the Spanish culture, Binondo has remained without much change as a reminiscence of the Chinese in Southeast Asia. In Binondo, especially Escolta Street, which earned the reputation as the queen of Manila streets for a period, was the primary of those vibrant districts of the city with their shopping centres?

Across the Pasig River from Intramuros is Manila's Chinatown, Binondo. This is not only the second oldest part of the inner-city area, but by some accounts, this is also possibly one of the oldest Chinatowns in the world (Chu and See, 2016). When Manila was officially opened to world trade in 1814, the Chinese traders gained dominance in the retail trade due to financial cooperation among themselves, greatly aided by credit provided by merchants other than Spaniards such as the British and Americans (Quirmo, 2010). It was because of this that Binondo became a commercial and financial center. It also became the choice of residence for Manila's rich people (Cruz, 2017). For this reason, two of Binondo's streets, Escolta and Rosario came to be important as these were where most of the Chinese shops were located. When the Americans created the city of Manila as what it is now, Binondo remained the center for commerce and finance. Escolta Street grew to be a major commercial street with some of Manila's earliest cinemas, cafes and department stores. It was here that innovation such as elevators was introduced to the Filipino public. The street attracted business professionals such as lawyers, accountants, and stockbrokers. Because of this, Escolta became the site where some of Manila's most modern buildings were built. Among them the Regina Building, the Crystal Arcade, and the Perez Samarillo (today First United Building) may be listed. Escolta Street managed to survive the invasion of the Japanese Army at the start of World War 2. But by the end of the war, many of its buildings were bombed or set on fire. Escolta was able to rebuild and managed to restart its commercial activities after the war. However, Escolta gradually lost its significance due to the emergence of new commercial centers in different parts of Manila. ${ }^{8}$

In Escolta Street, where the Spanish colonial architecture was once observed with all its aspects, the historical buildings of cultural importance have significantly lost their asset value due to urban corruption. Destruction of the buildings under heavy air raids during World War II and abandonment of the city by commercial enterprises migrating to other commercial areas, have played a determining role in it (Cruz, 2017).

The conservation movement in Binondo is largely based on economic motives, rather than the stimulus for the conservation of the historical and cultural heritage of the area. With the conservation of the buildings by small-scale private enterprises and through re-functioning efforts, they were transformed and started to be used for recreational and touristic purposes. Examples of this have increased noticeably in recent years.

In Escolta, the inner-city area has been conserved; buildings have been rehabilitated by repair and renovated for use. These historical spaces have gained economic value as locations for recreational purposes. Areas that have been invaded by street vendors and street stallholders until recently are now significantly recovered from this negative image of the past. Likewise, the city authorities have cleaned the areas having clusters of small commercial enterprises, especially from street vendors by means of large-scale evacuations.

In Binonda, the buildings rehabilitated by means of conservation by private sectors to a large extent, are located in Escolta Street. Here, historical buildings have decreased real property values due to deterioration. However, in Escolta Street, rehabilitation of some historical buildings by conservation and their use for different purposes (such as cafes, exhibition space, and gift shops etc.) have actually laid the foundation for the appreciation of the area again..$^{9}$ As a result, the spaces whose urban land value has decreased for a time, have now become favourite spaces of the city and the area has succeeded in remaining a central business location of the city.

7 Among the first settlements of the Spanish in Manila, Escolta was established in 1594. In the prosperity period based on commercial activities between Manila and Acapulco, it has gained a commercial identity, largely Chinese in character, Escolta gained the reputation as the Queen of the Manila Streets (Cruz, 2017).

8 But by the 1970s and 1980s, it was losing out to new commercial centres in areas like the Ortigas Centre in Quezon City/Mandaluyong City and the Ayala Commercial Centre in Makati City. Escolta was unable to keep up with the competition and shops and establishments here began moving elsewhere or closed altogether.

9 In fact, although land prices increased in the 1980s in a surprising way up to 2,000\% (Bankoff, 2003, p.103), the urban problems towards the 1990s which were considered as deterioration and corruption decreased their asset values. However, after the 2010s, especially upon successful renovations and rehabilitations on buildings basis, property values of the buildings started to increase again. 


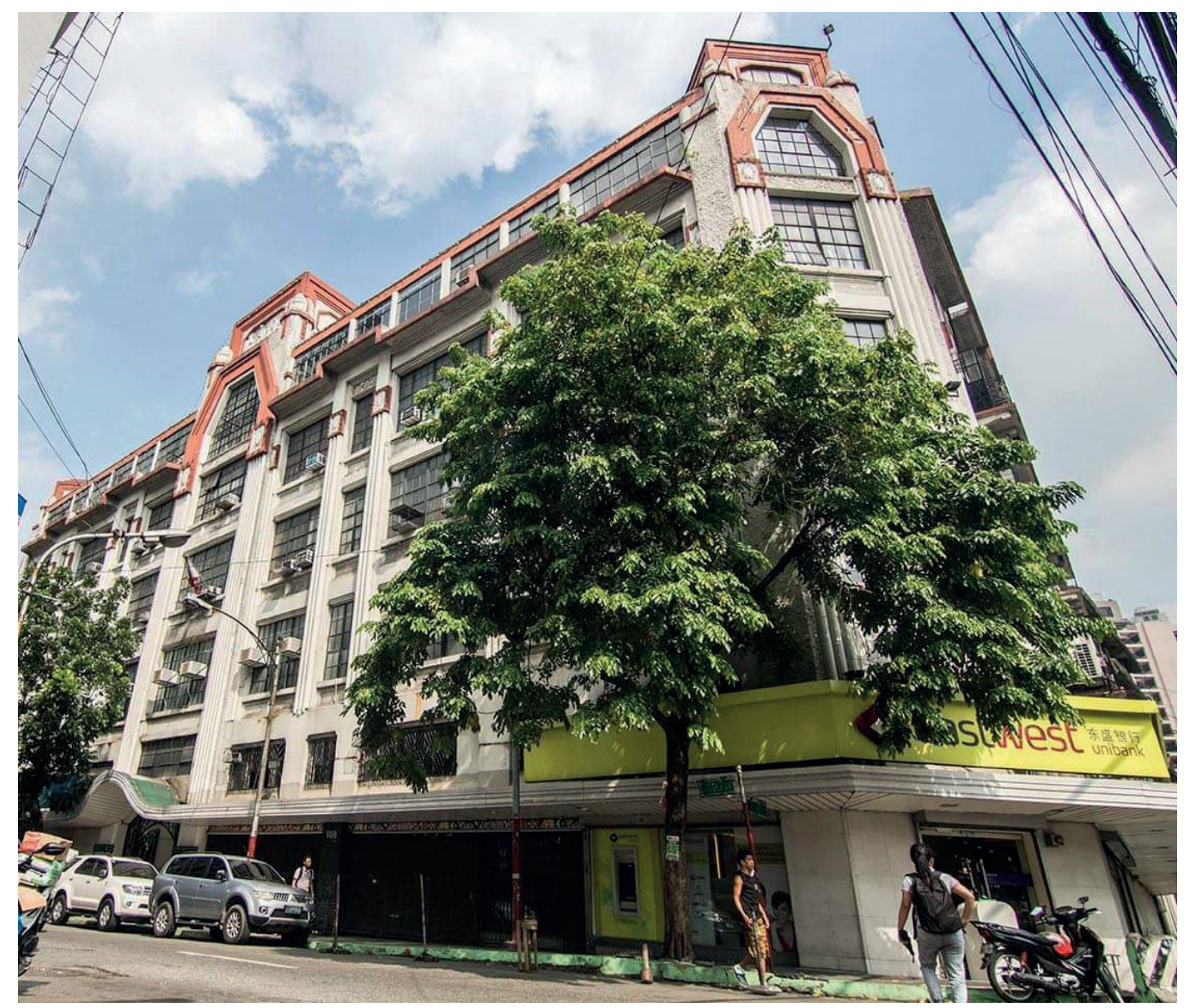

Photo 8: First United Building in Escolta.

We see an increased number of historical structures that have gained tourism-related functions through arrangements on a building basis. The First United Building (1929) is among the structures to which recreational function was imparted by restoration at the building scale. Constructed at the focal point of the commercial and business center in Manila, the First United Building has also taken its share from depreciation in the value of the buildings in its vicinity until recently. However, with support of the building owners and local administrations in Escolta, and also as a consequence of a series of restoration works performed in 2011, the lower floors of the First United Building were largely transformed to shops selling souvenirs, and cafes serving the tourists and the upper floors to spaces where cultural events are organized (Photo 8).

Another important building which gained recreational function by rehabilitation is a building which opened in 1922 and where the Hong Kong Shanghai Bank has operated for long years. It was in around 2014 that new investors, led by a local bakery, brought the building. They then repurposed the building into a high-end café and restaurant known as the 1919 Grand Café. The investors chose 1919, the year when construction began on the building, as the name the café. Since it was opened, the café has become popular among local and foreign visitors to enjoy a meal and see the restoration done inside the building.

In addition to these, the cultural identities of the districts pertaining to the Chinese were also maintained. In Binondo, along with the architectural buildings reflecting cultural identities of the Chinese, many workplaces have become commercial spaces where goods used by the Philippines of Chinese origin in their daily life and rituals are sold.

\subsubsection{Quiapo: An Example of Cultural Appearance Changed by Immigration}

Along with Binondo, Quiapo is another important district where the urban conservation phenomenon in Manila is continued at the building scale. While the district of Quiapo, an important part of the inner-city area in Manila, had been a district where political elites and rich people lived up to the 1930s (Venida, 2002, p. 63), it has become a district of poverty overtime, especially after the 1950 s, due to a number of factors: 
Known as the heart of Manila, Quiapo was established by the River Pasig, one of the biggest rivers in the country. Prior to the arrival of the Spanish, the location was a fishing town. However, the transfer of some important religious buildings by the Spanish to this location and start of trade with Manila has been a turning point for the area. Quiapo has gained important as a significant trade point for the Asian merchants of different ethnical origin in the period of 1571 and 1815. Especially Chinese and Japan merchants were pioneers of the trade in the area. Additionally, with the increased settlement of the Spanish and Western merchants in the location, Quiapo has gained a homogenous structure in the course of time. Quiapo became prominent as a district dwelled by the rich and well-educated families that played an important role in the development of the Philippines between the $19^{\text {th }}$ and $20^{\text {th }}$ centuries. In the late $19^{\text {th }}$ century, Calle Sebastian Street was regarded as the most beautiful street in Manila due to its mansions of rich architectural characteristics. Just at the beginning of the $20^{\text {th }}$ century, some mansions have been converted to student hostels due to the establishment of universities and colleges in Quiapo and its vicinity. However, urban corruption started particularly upon settlement of the Muslim groups from Mindano Island after the 1950s. Increased number of these population groups fled from the war has caused the abandonment of the rich families dealing with trade-in Quiapo, resulting in replacement of them by the families migrated from the rural areas. Due to increased Muslim population in the 1970s (mostly immigrants from Mindano Island which has a concentrated population of Muslims), the Golden Mosque was constructed and thus the architectural and cultural geographical appearance of the area has dramatically changed over time. ${ }^{10}$

The cultural identity and economic structure of Quiapo gradually changed between the 1950s and the 1980s. By the $1980 \mathrm{~s}^{11}$, the district began to be associated with crime and poverty (Yu, 2002). For this reason, the elite dwellers abandoned Quiapo and the decent urban structure of Quiapo degenerated upon settlement of a low-income population group. The historical conservation phenomenon in this old district of Manila is changing, albeit slowly, at the building scale.

In Quiapo, particularly the Golden Mosque and its immediate vicinity called Bahay Nakpil, densely populated by the Muslims, are primary places frequently visited by local and foreign people. Because of small-scale environmental arrangements particularly in the vicinity of Golden Mosque and Bahay Nakpil, they gain economic value as appropriate locations for visitors.

Renovation movement in connection with the buildings that gained new functions as a result of restoration works performed at the building scale now continues in the inner-city area and its immediate surroundings. For example, we see that historical buildings outside the inner-city area are also restored and particularly transformed to accommodation facilities in accordance with the taste of foreign visitors.

In addition to the works on district and building basis, the River Pasig, a part of the inner-city of Manila and water bodies connected to it, which have been heavily polluted with industrial and domestic waste, have been rehabilitated by means of rehabilitation projects funded by the Asia Development Bank (Steinberg, 2008). Efforts for the improvement of water quality and biological diversity in the river and relocation of the slums on its banks became a part of the local administration policies after the 2010s.

Also, open green areas in the immediate vicinity of the historical core (Intramuros) of Manila were rearranged and transformed into significant urban recreational spaces for local and foreign tourists. This area of historical importance, known as Rizal Park, which accommodates a variety of historical physical assets, contains the National Philippines Museum, National Library of the Philippines, Building for Department of Tourism, and a gallery of the heroes of the country. While the spectacular museums of historical structure in Rizal Park, which meets openair recreational demand of the local and foreign tourists, are maintained, the vicinity of the Park has gained new functions (e.g. arrangement of food-beverage areas, Japanese and Chinese botanic parks, the arrangement of walkways) and thus this historical recreational area has become a vivid recreational area which attracts the most local and foreign visitors in the country.

Although the area has been rehabilitated in various ways through urban renovation applications, the ever-increasing vehicle traffic in Manila poses a threat to historical buildings and makes the area inappropriate for pedestrians. ${ }^{12}$

10 This information about Quiapo were taken from Bahay Nakpil Bautista' House, the works "Revitalizing the City through Heritage" Fernando N. Zialcita (2006) and "Anson Yu's District of Hope: Walking tour of Quiapo (2002)"

11 For detailed information see Anson Yu's District of Hope: Walking tour of Quiapo (2002).

12 According to Global Economic Data, Indicators, Charts \& Forecasts (CEIC) data, while the number of registered motor vehicles in the Philippines was about 1 million in 1981, it reached to 12 million in 2018. 


\section{CONCLUSION}

The efforts for the rehabilitation of historical structures located in the inner-city areas of cities to endow them with touristic functions in Europe as well as in developed countries such as the USA, are also frequently encountered in other countries of the world. One of these countries is the Philippines, which is also one of the Pacific Edge countries. Particularly the historical inner-city of Manila, the colonial capital city of the Philippines, draws attention to the increasing role of tourism in terms of urban conservation. Examples of urban conservation and spatial distribution of them in recent years also prove this fact.

Unlike Singapore, the USA, and West European countries, we do not see large-scale conservation movements for the conservation of old historical buildings in Manila. Rather, we see renovation and rehabilitation efforts, particularly at the district and building scales.

In Intramuros and Binondo, which constitute the inner-city area of Manila, most of the historical buildings and districts themselves were heavily destroyed due to air raids during World War II, this has prevented the buildings of historical value from surviving. However, the inner-city of Manila underwent a change as a result of urban renovation practices and touristic-recreational spaces like hotels and cafes have started to be dominant in the geographical view of the city. Thanks to rehabilitation of the buildings in the historical inner-city areas to make them functional by economic motives, they make these areas gain economic functionality on the one hand and create an opportunity for "effective conservation" on the other hand. These spaces provide service to foreign tourists rather than local people.

Investments made by foreign and local investors in recent years, particularly for historical buildings remaining in the innerarea of the city indicate that the phenomena of renovation and conservation have been slowly adopted by the society. In Binondo and Intramuros, transformation of old buildings to hotels or cafes is important as an example in this regard.

In the areas where Spanish heritage constitutes the nucleus for tourism, urban restoration works at the building scale are noticeable. Restoration works at the building scale are largely performed as a part of the investments made by private companies or businessmen. Old buildings are restored and then they are reused by imparting new functions to them.
In the world, along with countries like Italy, France, and Germany with their well-established cities, even countries settled in relatively recent times like the USA, Australia and New Zealand have completely institutionalized conservation of the traces of spatial structures of historical background. As frequently seen in Southeastern Asia, particularly in those colonial capital cities which were established by the Western countries and which have rich historical/cultural resources (e.g. Hanoi, Phnom Pen, Jakarta, etc.), "urban conservation" has increasingly become an integral part of urban planning policies in historical coastal cities, except for Manila, in the Philippines (e.g. Davao, Cebu, Iloilo, Zamboange, Vigan, etc.).

Acknowledgments: I am grateful to Anson YU for his contributions to the fieldwork in Manila as well as the support he provided for writing this paper

Peer-review: Externally peer-reviewed.

Conflict of Interest: The authors have no conflict of interest to declare.

Grant Support: The authors declared that this study has received no financial support

Hakem Değerlendirmesi: Dış bağımsız.

Çıkar Çatışması: Yazarlar çıkar çatışması bildirmemiştir.

Finansal Destek: Yazarlar bu çalışma için finansal destek almadığını beyan etmiştir

\section{REFERENCES/KAYNAKÇA}

Ahunbay, Z. (2017). Tarihi Çevre, Koruma ve Restorasyon, İstanbul: Yem Yayın.

Bankoff, G. (2003). Constructing vulnerability: the historical, natural and social generation of flooding in metropolitan manila. Disasters, 27(3), 95-109.

Bankoff, G. (2006). Fire and quake in the construction of Old Manila. The Medieval History Journal, 10 (1-2), 411-427.

Beltran, J. V. (1982). The concept of urban renewal in metropolitan Manila: an analysis (Doctoral dissertation, University of Tasmania).

Berner, E. (1988). Poverty alleviation and the eviction of the poorest: urban land transfer programs in the Philippines, Institute of Social Studies, Working Paper Series No, 282.

Broudehoux, A. M. (1994). Neighborhood regeneration in Beijing: An overview of projects implemented in the inner city since 1990 (Doctoral dissertation, McGill University Libraries).

Caoili, M. A. (1988). The Origins of Metropolitan Manila: A Political and Social Analysis, Quezon City: New Day Publishers.

Castells, M., Goh, L., \& Kwok, R. Y. W. (1990). The Shek Kip Mei syndrome: economic development and public housing in Hong Kong and Singapore, Pion Limited.

Chu, R. T., See, T. A .(2016). Toward a History of Chinese Burial Grounds in Manila during the Spanish Colonial Period, Chinese Deathscapes in Insulindia (92), 63-90. 
Chua, B. H. (2016). Between Economy and Race: The Asianization of Singapore. Zed Books.

Cruz, G. R. (2017). The Cultural Heritage-Oriented Approach to Economic Development in the Philippines: A Comparative Study of Vigan, Ilocos Sur and Escolta, Manila. In 10th DLSU Arts Congress.

Dadak, K. (2015). Yeni Kuşak Hak Olarak Çevre Hakkı, Uyuşmazlık Mahkemesi Dergisi, (5), 309-326.

Davis, M. (2006). Planet of Slums. New Perspectives Quarterly, Verso, New York.

De Roos, R. (1966). The Philippines: Freedom's Pacific Frontier. National Geographic, 130, 301-351.

Eldem, N., Atilla, Y., Kamil, M. (1979). Sultanahmet Meydanı Çevresi ve Ayasofya Soğukçeşme Sokağı Koruma ve Geliştirme Projesi.

Emekli, G. (2011). Öğrenen turizm bölgeleri, kentler ve kent turizmine kuramsal yaklaşım. Ege Coğrafya Dergisi, 20 (2), 27-39.

Flieger, W. (1977). Internal Migration in The Philippines During The 1960's, Philippine Quarterly Of Culture And Society, Vol. 5, No.4. Pp.199-231.

Gottmann, J. (1976). Şehirsel Merkeziyetin Gelişmesi. (Translate by N. Özgüç). İstanbul: İstanbul Üniversitesi Yayınları.

Güngör, Ş. \& Uysal, A. (2019). Film tourism: The influence of film and tv series on the tourism activities in Nevşehir. International Journal of Geography and Geography Education, 39, 189-202.

Hall, M. C. \& Page, S. J. (2006). The Geography of Tourism and Recreation, Environment, Place and Space. Routledge: London and New York.

Harvey, D. (2012). Rebel Cities: From the Right to the City to the Urban Revolution, VERSO London, New York.

https://www.ceicdata.com/en . Access time: 19.08.2019.

Kapan, K. (2018). Turizm faaliyetlerinin şehirsel gelişmeye etkileri: Antalya örneği, Coğrafya Dergisi, 37, 47-56.

Kapan, K., Yulu, A., \& Yu, A. (2018). Filipinler'de turizm faaliyetlerinin tarihsel gelişimi. Marmara Coğrafya Dergisi, (37), 144-151.

King, A. (1996). Çeperlerin merkeze dahil edilmesi. Kent ve Kültürü, (8), 193-210.

Mullins, P. (1994). Class relations and tourism urbanization: the regeneration of the petite bourgeoisie and the emergence of a new urban form. International Journal of Urban and Regional Research, 18 (4), 591-608.

Munárrız, L. T. M., Perez, P. J. A., Caguımbal, R. S. (2015). Urban renewal of the city of Manila and its impact to environment and physical design: Where can we go from here?, Journal Of Architecture And Allied Arts in The Philippines.
Öncü, A., Weyland, P. (1997). Space, Culture and Power: New Identities in Globalizing Cities, Zed Books.

Özgüç, N. (1988 -1992). Şehirsel koruma ve coğrafya. Coğrafya Dergisi, $3,61-122$.

Özgü̈, N. (2017). Turizm coğrafyası Özellikler ve Bölgeler. Çantay Kitabevi: İstanbul.

Park, R. E. (1967). On Social Control and Collective Behavior. University of Chicago Press.

Quirıno, C. (2010). Philippines Cartography, 1320-1899, Vibal Foundation.

Rewtrakunphaiboon, W. (2009). Film-induced tourism: Inventinga vacationto a location.

Shaukland, G. (1996). Tarihi değeri olan kentlere neden el atmalıyız, Kent ve Kültürü, Cogito Dergisi, (8), 23-35.

Smith, N. (2008). Uneven Development: Nature, Capital, and the Production of Space, University of Georgia Press.

Smith, R. A. (1988). The Role of Tourism in Urban Conservation, The case of Singapore. Butterworth \& Co. Ltd. 5(3), 245-259.

Steinberg, F. (2008). Revitalization of historic inner-city areas in Asia: The potential for urban renewal in Ha Noi, Jakarta, and Manila. Asian Development Bank.

Tekeli, İ. (2014). Kent, Kentli Hakları, Kentleşme ve Kentsel Dönüşüm, İstanbul: Tarih Vakfı Yurt Yayınları.

Tester, K. (1987). Chinese Architecture. Urban Planning and Landscape Design: A Series of Essays. Gainesville, Florida: Florida Architecture and Building Research Center.

Tümertekin, E. (1997). Coğrafya ve Bu Kitap Üzerine, İstanbul İnsan ve Mekân. İstanbul: Tarih Vakfı Yurt Yayınları, İstanbul.

Tümertekin, H. (1988). Tarihsel Koruma ve Yakın Yıllarda İstanbul'daki Koruma Örnekleri, İstanbul Üniversitesi Sosyal Bilimler Enstitüsü, Yayınlanmamış Yüksek Lisans Tezi.

Vaughan, J. B. (1956). The Land and People of the Philippines, J.B. Lippincott Company, Philadelphia and New York.

Venida, V. S. (2002). Conflicts over heritage: The Case of Quiapo. Kritika Kultura, 2, 55-74.

Williams, S. (1998). Tourism Geography. Routledge, Taylor and Francis Group, London and New York.

Yu, Anson (2002) District of hope: Walking tour of Quiapo, Colors Philippines, 1(2), 40-53.

Zialcita, N. F. (2006). Revitalizing the city through heritage, Quiapo: Heart of Manila, Ateneo de Manila University.

Zukin, S. (1995). The Cultures of Cities, Blackwell. Cambridge, MA. 
